\title{
Institutional Quality in Central and East European Countries and Its Impact on FDI Inflow
}

\author{
Tomasz Dorożyński, Bogusława Dobrowolska, Anetta Kuna-Marszałek
}

\begin{abstract}
A B S T R A C T
Objective: To verify the quality of institutional environment and its role in attracting foreign direct investment (FDI). The article attempts to provide a quantitative description of the impact of institutional quality (IQ) on FDI inflow to 17 countries of Central and Eastern Europe (CEECs) in 2007-2017.
\end{abstract}

Research Design \& Methods: Firstly, we reviewed studies dedicated to the relationship between institutional operations and investment attractiveness. Then, we selected 17 CEECs and ranked them for the value of FDI in absolute terms and as a share of GDP. The third stage focused on building an original set of indicators. We used selected categories of Global Competitiveness Index (GCl). Based on rankings, in the fifth stage, we divided 17 CEECs into groups representing similar IQ using hierarchical cluster analysis. The final stage consisted in examining the impact of IQ on the inflow of FDI within a selected group of countries by estimating dynamic panel data models.

Findings: The study demonstrated that CEECs differ with respect to IQ; an aspect that exerts a statistically significant impact on FDI inward stock as \% of GDP.

Implications \& Recommendations: The study has implications for research and practice. The results may be interesting for policymakers and may have an application value for institutions. An efficient and effective institutional system may importantly contribute to the boosting of investment attractiveness of countries and impact FDI flows.

Contribution \& Value Added: The article sheds more light on the discussion about the relevance of IQ as a factor determining FDI inflow. The added value of this article consists in grouping 17 CEECs based on their similarity with respect to IQ and demonstrating that it impacts the size of FDI inflow. We proposed an original set of indicators for these countries that help in identifying their IQ.

\begin{tabular}{ll}
\hline Article type: & research article \\
& FDI; institutions; institutional quality; hierarchical cluster analysis; \\
& panel models
\end{tabular}

JEL codes: $\quad$ F21, F23

Received: 3 September $2019 \quad$ Revised: 6 January $2020 \quad$ Accepted: 6 January 2020

\section{Suggested citation:}

Dorożyński, T., Dobrowolska, B., \& Kuna-Marszałek, A. (2020). Institutional Quality in Central and East European Countries and Its Impact on FDI Inflow. Entrepreneurial Business and Economics Review, 8(1), 91-110. https://doi.org/10.15678/EBER.2020.080105 


\section{INTRODUCTION}

Foreign direct investment is viewed as a beneficial and safe form of international capital flows and a way to finance development processes. For that reason, for many decades already, countries around the world become increasingly eager to open up their economies and create conditions to attract FDI understood as an important stimulator of productivity enhancement, technological advancement, and job creation. Determinants of FDI location are associated with conditions favourable for conducting economic activities within a given area. These conditions create the investment climate in individual locations.

There is a long list of location-specific attributes which impact FDI inflow. Independent variables include economic and social stability, taxes, institutions, the size of host market, the cost of labour, the availability and quality of infrastructure, and political risk. We want to focus on the institutional aspects and their role in attracting FDI. We observed that the literature recently becomes increasingly interested in the institutional setting that surrounds FDI, in particular in developing countries, where institutional quality significantly differs from what we can expect of developed countries (Bailey, 2018; Jabri \& Brahim, 2015). The dominant view is that countries with better institutional quality can attract more FDI. Poor quality institutions hinder FDI inflow acting like a tax (Buchanan, Le, \& Rishi, 2012). The host country's institutional quality "affects profitability, and institutionally strong countries can attract foreign investors by offering high returns" (Sabir, Rafique, \& Abbas, 2019, p. 4). In other words, countries with weaker institutions perform poorly, while countries with better institutions tend to perform better (Hayat, 2019).

Our article aims to provide a quantitative description of the impact of institutional quality on FDI inflow into Central and Eastern Europe countries (CEECs) in 2007-2017. Our hypothesis is that institutional quality - measured with a set of selected indicators - impacts the FDI inward stock as \% of GDP. This article adds to the existing literature by addressing the following questions: (1) how can institutional quality be measured? (2) is institutional quality, as a determinant of FDI, equally important for CEECs? (3) what is the relevance of institutional quality, compared to other important determinants of investment attractiveness in attracting FDI, such as GDP per capita growth, inflation, employment, or merchandise trade? The analysis was conducted using hierarchical cluster analysis and panel models. Institutional quality along with the broadly understood investment attractiveness and its impact upon the size of FDI inflow into CEECs was previously the subject of our interest (e.g., Dorożyński, Dobrowolska, \& Kuna-Marszałek, 2019). Thus, the article can be seen as another attempt to demonstrate the importance of the relationship between the quality of institutions and FDI, this time using different methods of research analysis. The article is structured as follows. Section two contains literature review. Section three provides details on data and methodology, followed by section with results and discussion.

\section{LITERATURE REVIEW}

The relationship between the quality of institutional environment and FDI was examined extensively. Its relevance was highlighted quite a long time ago; however, over the last two decades FDI researchers began to attach greater importance (Bailey, 2018; Daniele \& Marani, 2006; Bénassy-Quéré, Coupet, \& Mayer, 2005). The subjects increasingly attracts 
researchers' attention especially in developing and transitioning countries (Jabri \& Brahim, 2015; Daude \& Stein, 2007).

There are many reasons why the quality of institutions does matter to foreign investors. Firstly, according to the institutional theory, enterprises operate in a complex and unstable environment, which is why their decisions are largely based on the performance of institutions that impact the development of investment environment (Francis, Zheng, \& Mukherji, 2009). Policymakers can influence capital structure and investment decisions - thus the cost of capital and company value - by controlling corruption, adopting quality regulations and ensuring the rule of law. Secondly, since policymakers may impact the capital structure of firms, by the same token they may determine the quality of corporate governance at company level (Lemma \& Negash, 2013). Finally, and most importantly, the presence of a high-quality institutional setting tends to add more credibility and security to MNEs, which translates into lower investment transaction costs, sunk costs included (Daniele \& Marani, 2006).

In other words, (1) good governance helps firms to increase their productivity; (2) poorly performing institutions can raise additional costs as they may act like a tax inflicting cost on FDI investors; and (3) poor institutional quality can further increase uncertainty, leading to firms' higher vulnerability (Buchanan, Le, \& Rishi, 2012; Bénassy-Quéré et al., 2005; Daude \& Stein, 2007). The key role in deterring FDI play the unpredictability of laws, regulations, and policies, government instability, excessive regulatory burden, and lack of commitment (Daude \& Stein, 2007). Investors are unwilling to invest in countries where institutions encourage corruption and nepotism (Mengistu \& Adhikary, 2011). On the other hand, there is research (Hausmann \& Fernández-Arias, 2000), which openly suggests that countries representing "lower" institutional quality paradoxically lure more foreign capital, because there are investors who prefer doing business in a more complex investment environment, as the cost of entering such markets is lower compared to other economies.

Researchers agree that institutions - be it regional, national, or even supranational shape the nature of business by providing the framework of opportunities and constraints within which economic activity takes place (Nielsen, Asmussen, \& Weatherall, 2017), which implies that the quality of the host country institutions should impact FDI location decisions. Moreover, some try to prove that better quality institutions enhance FDI-induced economic growth - especially in low-income and middle-income countries (Hayat, 2019) - as institutional quality is to modulate the effect of FDI on economic growth in developing countries (Jude \& Levieuge, 2015). From the perspective of this group of economies, such conclusion seems worthwhile.

Moreover, what is important is policy flexibility, as it gives politicians more leeway to use investment incentives to attract foreign investors. According to Zheng (2011), foreign investors generally prefer a policy environment with low political risk and consistent policy agenda, but they also like a flexible environment in which the government has the capacity to address their particular needs. In result, institutional differences between countries may be a source of comparative advantages (Levchenko, 2004). Hence, some sectors are more "institution-intensive" than others, which could be a source of more trade or investment flows.

The relationship between institutional quality and FDI inflows is illustrated by many factors, such as political regime (Madani \& Nobakht, 2014; Guerin \& Manzocchi, 2009), 
democratic institutions and political stability (Jensen, 2008; 2003; Brada, Kutan, \& Yigit, 2006), corruption (Habib \& Zurawicki, 2010; Al-Sadig, 2009), tax policies (Eicher, Helfman, \& Lenkoski, 2011; Feld \& Heckemeyer, 2008), property rights (Tanaka \& Iwasako, 2014; Khan \& Samad, 2010), quality of educational system (Miningou \& Tapsoba, 2017) or security (Essien, Barikui, Abuba, \& Igbara, 2015; Stoian \& Vickerman, 2005). Due to the multiplicity of factors that shape the above-mentioned institutional quality, the literature on its impact upon FDI can be divided into three strands (Kurul \& Yalta, 2017). The first strand focuses mainly on identifying the effects of a specific institutional dimension, such as the influence of corruption or political regimes on FDI. The second strand analyses the importance of different dimensions of institutional quality. Finally, the third strand explores the effect of a composite institutional indicator, which is constructed by combining different dimensions of institutional variables.

Empirical results are vague, because it is hard to measure institutional factors. The reason may be that various researchers use different measures of institutional quality and look at different types of data - such as investing firms versus aggregate FDI inflows (Walsh \& Yu, 2010) - or differently define individual factors of institutional quality. As Ali, Fiess, and MacDonald (2010) rightly observe, measurement problems emerge also when a single factor is used to capture a complex broad phenomenon like institutions. Foreign investors are likely to base their investment decisions on overall institutional quality rather than on a single institutional aspect such as political stability or corruption. By using only one indicator in the analyses, we are most likely to underestimate the role of institutions in determining FDI inflows. Moreover, according to Arel-Bundock (2017) contemporary researchers tend to overemphasise the statistical significance of outcomes of their works and often neglect to assess the explanatory or predictive power of their theories. In other words, we need to be cautious in approaching the results of many studies that assume the powerful impact of institutional quality on FDI inflow. Finally, institutional quality quite often appears as a necessary but insufficient precondition to attract FDI (Masron \& Naseem, 2017).

Institutional quality is considered one of the leading factors that attract FDI independently of a country's level of economic development, and empirical results confirm that this level has a positive impact on FDI in all groups of countries. However, some researchers find that institutional quality has a greater impact on FDI in developed countries than in developing countries (Sabir et. al., 2019).

To sum up, there is substantial literature linking the quality of institutions with FDI inflows from the perspective of developed and developing countries, but also economies in transition. A vast majority of research in FDI mainly focuses on the regions of North and South America, Eastern Europe, South-East Asia, and Africa. Little attention in the research on FDI inflows and institutional quality focuses on Central and Eastern European countries (e.g., Dorożyński et. al, 2019). Within this gap we focus on the relationship between institutional factors and FDI flows in CEECs.

\section{FDI in Central and Eastern European Countries}

Central and Eastern Europe is often perceived by investors as a single entity, even though the countries of the region greatly differ with respect to their ability to attract FDI (Figure 1). Poland, the Czech Republic, and Hungary are the most effective in successfully competing for foreign investors. In 2017, the total value of the FDI inward stock in these three 
countries exceeded the value of FDI stock in all the other countries covered by the study taken together (ca. USD 480 bn compared to USD 408 bn).

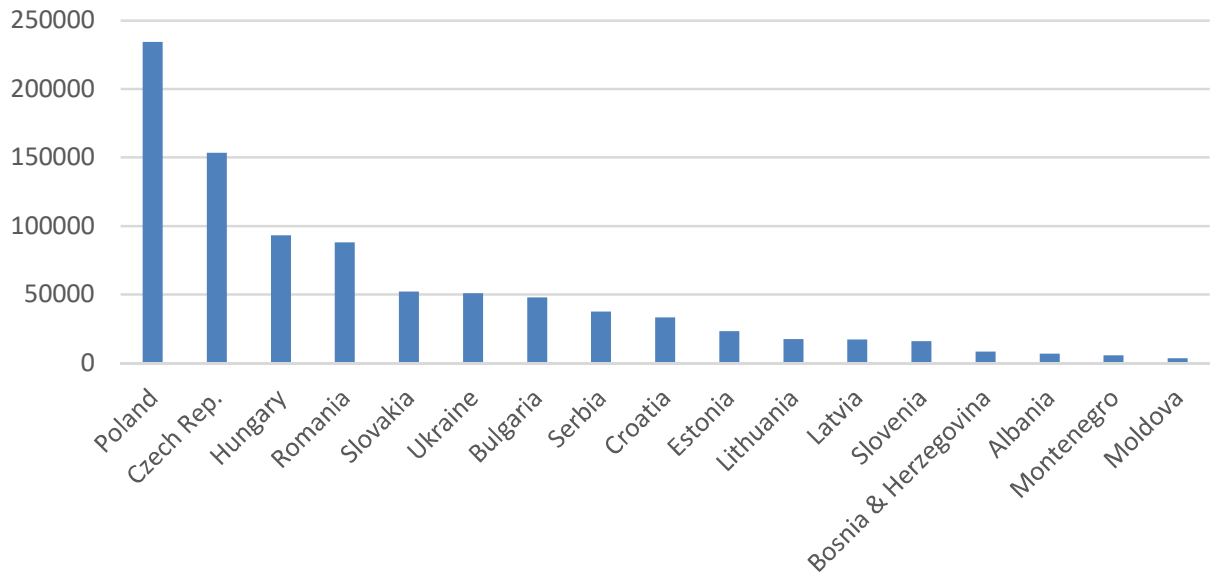

Figure 1. FDI inward stock (as at the end of 2017, in millions of USD) Source: World Investment Report UNCTAD (2018).

However, the examined values look different when we take into account the FDI inward stock as \% of GDP (Figure 2). Then we find out that the undisputed leader is Montenegro (116\%). Estonia, Bulgaria, and Serbia manage to attract FDI stock equivalent of ca. $90-80 \%$ of their GDP. Poland in this ranking occupies the 14th position among all the 17 CEE countries (44.68\%). At the bottom of the ranking is Slovenia with the share of FDI stock in GDP of $32 \%$. It is difficult to find regularities in this ranking that would address e.g. the impact of the size of the country or the impact of its EU membership.

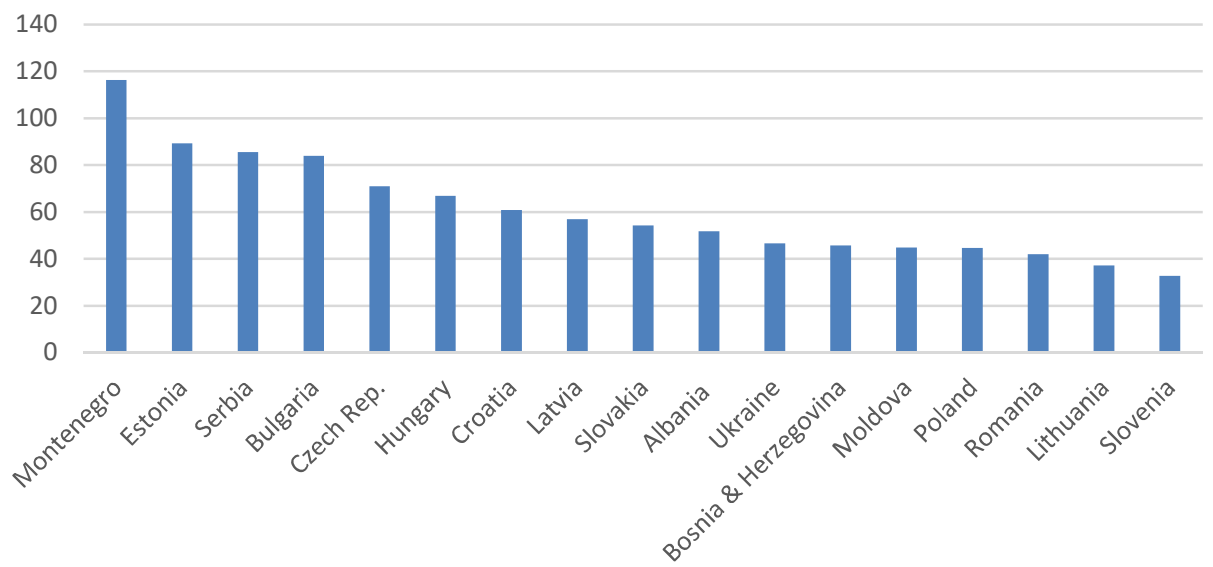

Figure 2. FDI inward stock as \% of GDP (as at the end of 2017) Source: own elaboration based on UNCTADSTAT. 


\section{MATERIAL AND METHODS}

\section{Institutional Quality Assessment Based on the Global Competitiveness Index}

The institutional performance of CEECs was assessed based on the Global Competitiveness Index $(\mathrm{GCl})$. The index is regularly published by the World Economic Forum since 1979. The $\mathrm{GCl}$ started with only one ranking, the Competitiveness Index, prepared under the supervision of Jeffrey Sachs and designed to identify the foundations of medium and long-term rapid economic growth. Then it gradually expanded with new indices. Some of them come from results of surveys conducted among thousands of corporate managers from almost all the countries included in the analysis; 138 countries in the edition 2016-2017 considered in this study.

The $\mathrm{GCl}$ presents the results in three main categories - basic requirements, efficiency enhancers, and innovation and sophistication factors - which address twelve policy domains called pillars. Each pillar is built of at least several detailed subcategories and their indices. The final assessment of a given economy is thus a derivative of over 100 different indicators. For our article we selected 23 indices that best describe institutional quality. Most of them come from the first pillar "Institutions" and from its "Part I: Public Institutions," ${ }^{11}$ which includes 16 detailed indices. Nevertheless, we decided that some indices from other pillars relate to institutional quality, although they have been included in other fields, e.g. education, market efficiency, or R\&D innovation (Figure 3). Many other authors believe that these inform about the institutional quality of a country, e.g.:

1. The quality of the educational system (Miningou \& Tapsoba 2017; Alesina \& Perotti, 1996): we may expect that a more educated population demands more transparent and dynamic institutions and permits to build them.

2. The effectiveness of an antimonopoly policy (Petersen, 2013): the better antitrust regimes protect the market against monopolies or cartels, the more intense competition between different suppliers and the better the institutions perform.

3. The effect of taxation on incentives to invest and work (Fatica, 2009; Feld \& Heckemeyer, 2008; Bénassy-Quéré, Fontagné, \& Lahrèche-Révil, 2003; Moore, 1998): a sound tax system enables the consolidation of a social contract that gives rise to a more demanding relationship between the state and citizens.

4. The relevance of trade barriers (Rodrik, Subramanian, \& Trebbi, 2004; Rigobon \& Rodrik, 2004): international openness creates a more dynamic, sophisticated, and demanding environment, which fuels demand for good institutions, encourages a more competitive environment, and may hinder corruption and nepotism.

5. Business impact of rules on FDI (Bruno, 2008): investors usually avoid investing in countries where regulations are unclear and often change and restrict competition. The better and more effective the institutions, the better development opportunities for the market.

6. Government procurement of advanced technology products (Lee \& Park, 2013): manufacturing of advanced technology products is linked, among other things,

\footnotetext{
${ }^{1}$ Besides "Part I" in the pillar "Institutions," there is also "Part II. Private institutions." The latter embraces two categories and five detailed indices that provide the assessment of such notions as corporate ethics and governance standards. We skipped "Part II" in our study and decided to focus on the assessment of public institutions performance.
} 
with intellectual property rights; thus, we may expect that more respect for intellectual property rights (IPR) means better perception of the quality of institutions in a given country.

All of the above-listed indicators help us to assess the institutional system of a given country from the viewpoint of, among other things, the enforcement of property rights, public institutions' interference in the economy, efficiency and transparency in the public sector, the quality of the education system, and labour market efficiency.

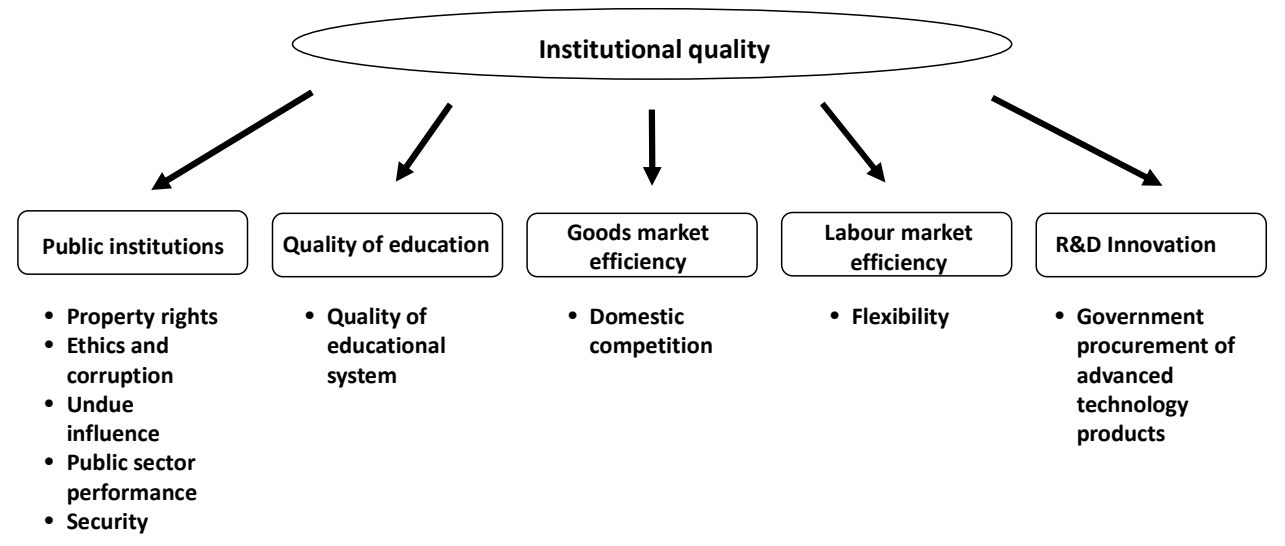

Figure 3. Key subcategories and indices of institutional quality

Source: own elaboration based on the World Economic Forum; GCI (2016-2017).

The 2016-2017 edition of GCl features only six CEECs in the top 50: Estonia occupies the highest, 30th place, followed by the Czech Republic (31), and Lithuania (35) with respective scores of $4.78,4.72$, and 4.60 on a scale from one to seven, with seven being the highest score. In this edition, institutions in the CEE countries score quite differently. When it comes to performance, Estonia is the undisputed leader (first rank among all the surveyed CEECs and 23rd globally), followed by Lithuania (second and 51st respectively), the Czech Republic (third and 54th), and Slovenia (fourth and 58th). Institutions in Bosnia and Herzegovina (15th and 126th), Moldova (16th and 128th), and Ukraine (17th and 129th) are considered the worst performers.

A detailed analysis of 23 individual subcategories of institutional quality further reveals substantial differences among the CEECs. Estonia clearly outperformed other CEECs in almost all the surveyed subcategories with first rank in 21 out of 23 variables. Slovenia, Macedonia, and Latvia scored relatively well to occupy top positions in a number of subcategories, which is indicative of relatively high indicators of institutional quality. The bottom of the ranking is as usually occupied by Ukraine, Slovakia, and Moldova (Table A1 in Appendix).

\section{Institutional Quality in 17 Central and Eastern European Countries in 2007-2017}

This part of the study focused on distinguishing 17 CEECs and grouping them based on similarities in institutional quality. To this end we deployed the Hierarchical Cluster Analysis. The method is a tool used to explore and identify natural clusters in sets of data, similar with respect to specific features (James, Witten, Hastie, \& Tibshirani, 2014; Lasek, 2002). 
The selection of diagnostic variables is crucial for the correctness of results obtained from the study. As we have already mentioned, variables in our case were selected based on the $\mathrm{GCl}$. For this article we selected the most relevant indicators that describe institutional quality. They come from several pillars encompassing a number of indices. For variables selected for further analysis we calculated basic descriptive statistics, which suggest that variation coefficient does not exceed $10 \%$ (Table 1 ) for only three variables; i.e. business costs of terrorism $(8.18 \%)$, business costs of crime and violence $(9.15 \%)$, and the relevance of trade barriers (8.39\%). However, we should bear in mind that the examined variables are treated as quantitative even though they are measured only at the ordinal level, on a scale from one to seven.

Ward's method was used to obtain a dendrogram illustrating the hierarchical structure of the set of objects assessed for their institutional quality in 2007-2017. A detailed analysis of the dendrogram allowed us to divide the 17 CEECs included in the study into five groups that exhibit strong similarity with respect to institutional quality (Figure 4):

1. Group I: Hungary, Romania, Slovakia, Croatia.

2. Group II: Latvia, Lithuania, Poland, Slovenia, Czech Republic.

3. Group III: Albania, Montenegro.

4. Group IV: Bosnia and Herzegovina, Serbia, Moldova, Ukraine, Bulgaria.

5. Group V: Estonia.

Estonia is an indisputable leader in institutional quality, which is why this country and group $\mathrm{V}$ were selected as the reference point for further analyses. Group II brings together runners-up in this ranking, i.e. Latvia, Lithuania, Poland, Slovenia, and the Czech Republic. A slightly worse score, although very close, was achieved by countries in group III, i.e. Albania and Montenegro (Table A2 in Appendix).

The above-presented division seems convincing, although one cannot find unambiguous linkages between countries in each and every case. Groups I and II are made of European Union member states. With the exception of Romania, all the other listed countries represent a similar level of economic development. Except Romania and Croatia, most of them launched economic and systemic transformations at the same time, cooperated with one another, and drew on each other's experiences. All these countries seek markets for their products mainly in Western Europe. For countries from group I Germany remains the main trade partner; only in Croatia Germany ranks second after Italy.

Group II includes countries similar at economic, political, and cultural levels. Their populations and markets are relatively small, with the exception of Poland. In all of the Group II countries foreign capital comes mostly from Western Europe; all of these economies work towards attracting FDI and, in doing so, they compete with each other.

Members of groups III and IV are countries in geographic proximity; only Ukraine and Moldova come from Eastern Europe, while the rest belong to South-Eastern Europe. All of them are the least affluent European countries. Only Bulgaria is an EU member state, with the rest of the countries aspiring to EU membership. On top of that, Montenegro, Serbia, and Bosnia and Herzegovina are linked with historical bonds, as these countries emerged after the breakup of Yugoslavia in the 1990s. 
Group V is composed of Estonia, a country clearly different from the rest of countries examined with respect to their economic development. Its economy rests on openness, liberal economic policy, but also on tax and banking system that is enterprise- and investment-friendly. The country is very active in the area of innovation, automation, and digitalisation, in which it is also a leader in the EU.

Table 1. Potential diagnostic variables for institutional quality in CEECs and basic descriptive statistics for the examined general population

\begin{tabular}{|c|c|c|c|c|c|c|c|}
\hline Symbol & Variables & $\begin{array}{c}\text { aver- } \\
\text { age }\end{array}$ & $\begin{array}{l}\text { vari- } \\
\text { ance }\end{array}$ & $\begin{array}{c}\text { between } \\
\text { groups } \\
\text { variance }\end{array}$ & $\begin{array}{c}\text { within } \\
\text { groups } \\
\text { variance }\end{array}$ & \begin{tabular}{|l|} 
stand- \\
ard de- \\
viation
\end{tabular} & $\begin{array}{l}\text { variation } \\
\text { coeffi- } \\
\text { cient (\%) }\end{array}$ \\
\hline \multicolumn{8}{|c|}{ Pillar 1: Institutions/index: Public institutions } \\
\hline $\mathrm{X}_{1}$ & Property rights & 3.91 & 0.44 & 7.03 & 0 & 0.66 & 16.88 \\
\hline $\mathrm{X}_{2}$ & Intellectual property protection & 3.58 & 0.42 & 6.66 & 0 & 0.65 & 18.16 \\
\hline $\mathrm{X}_{3}$ & Diversion of public funds & 3.15 & 0.38 & 6.00 & 0 & 0.61 & 19.37 \\
\hline $\mathrm{X}_{4}$ & Public trust in politicians & 2.39 & 0.23 & 3.75 & 0 & 0.48 & 20.08 \\
\hline$X_{5}$ & Irregular payments and bribes & 4.07 & 0.52 & 8.32 & 0 & 0.72 & 17.69 \\
\hline $\mathrm{X}_{6}$ & Judicial independence & 3.38 & 0.73 & 11.73 & 0 & 0.86 & 25.44 \\
\hline$x_{7}$ & $\begin{array}{l}\text { Favouritism in decisions of government } \\
\text { officials }\end{array}$ & 2.74 & 0.26 & 4.09 & 0 & 0.51 & 18.61 \\
\hline $\mathrm{X}_{8}$ & Efficiency of government spending & 2.79 & 0.34 & 5.44 & 0 & 0.58 & 20.79 \\
\hline$X_{9}$ & Burden of government regulation & 2.99 & 0.33 & 5.33 & 0 & 0.58 & 19.40 \\
\hline$X_{10}$ & $\begin{array}{l}\text { Efficiency of the legal framework in } \\
\text { settling disputes }\end{array}$ & 3.03 & 0.26 & 4.07 & 0 & 0.50 & 16.50 \\
\hline$X_{11}$ & $\begin{array}{l}\text { Efficiency of the legal framework in } \\
\text { challenging regulations }\end{array}$ & 2.95 & 0.24 & 3.90 & 0 & 0.49 & 16.61 \\
\hline $\mathrm{X}_{12}$ & Transparency of government policymaking & 3.95 & 0.26 & 4.14 & 0 & 0.51 & 12.91 \\
\hline $\mathrm{X}_{13}$ & Business costs of terrorism & 5.87 & 0.28 & 3.66 & 0 & 0.48 & 8.18 \\
\hline $\mathrm{X}_{14}$ & Business costs of crime and violence & 5.03 & 0.21 & 3.32 & 0 & 0.46 & 9.15 \\
\hline $\mathrm{X}_{15}$ & Organised crime & 5.03 & 0.47 & 7.73 & 0 & 0.69 & 13.72 \\
\hline $\mathrm{X}_{16}$ & Reliability of police services & 4.13 & 0.41 & 6.47 & 0 & 0.64 & 15.50 \\
\hline \multicolumn{8}{|c|}{ Pillar 2: Higher education and training/index: Quality of education } \\
\hline $\mathrm{X}_{17}$ & Quality of the education system & 3.59 & 0.23 & 3.66 & 0 & 0.48 & 13.37 \\
\hline \multicolumn{8}{|c|}{ Pillar 3: Goods market efficiency/index: Domestic competition } \\
\hline $\mathrm{X}_{18}$ & Effectiveness of antimonopoly policy & 3.66 & 0.24 & 3.81 & 0 & 0.48 & 13.11 \\
\hline $\mathrm{X}_{19}$ & Effect of taxation on incentives to invest & 3.26 & 0.31 & 5.02 & 0 & 0.56 & 17.18 \\
\hline $\mathrm{X}_{20}$ & Relevance of trade barriers & 4.53 & 0.14 & 2.29 & 0 & 0.38 & 8.39 \\
\hline$X_{21}$ & Business impact of rules on FDI & 4.34 & 0.43 & 6.94 & 0 & 0.66 & 15.21 \\
\hline \multicolumn{8}{|c|}{ Pillar 4: Labour market efficiency/index: Flexibility } \\
\hline$X_{22}$ & Effect of taxation on incentives to work & 3.08 & 0.21 & 3.42 & 0 & 0.46 & 14.94 \\
\hline \multicolumn{8}{|c|}{ Pillar 5: R\&D Innovation } \\
\hline$x_{23}$ & $\begin{array}{l}\text { Government procurement of advanced } \\
\text { technology products }\end{array}$ & 3.16 & 0.13 & 2.15 & 0 & 0.37 & 11.71 \\
\hline
\end{tabular}

Source: own compilation based on $\mathrm{GCl}$. 


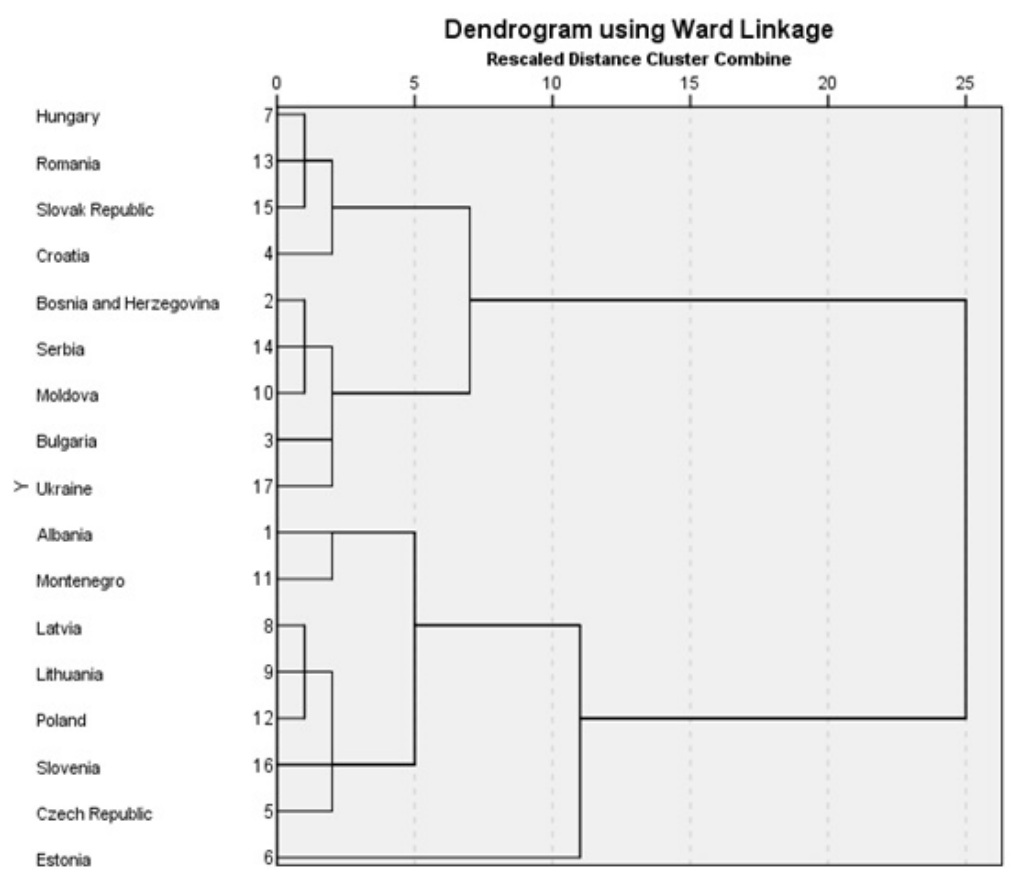

Figure 4. Dendrogram of average institutional quality for 17 CEECs for 2007-2017 obtained using Ward's method (Ward's linkage)

Source: own elaboration.

\section{Panel studies}

Collected statistical data are structured in a panel (2007-2017), in which a calendar year is the principal period, while its objects are 15 countries $^{2}$ of Central and Eastern Europe. When exploring FDI inflows, attention is paid to their sustainability, because effects achieved in the past are decisive for current performance. Given the dynamic nature of examined occurrences and how they intertwine with panel data, we used dynamic panel data models.

In general form, a dynamic panel data model can be presented as follows:

$$
\begin{gathered}
y_{i t}=\gamma y_{i, t-1}+\boldsymbol{x}_{i t}^{T} \boldsymbol{\beta}+u_{i t}=\gamma y_{i, t-1}+\boldsymbol{x}_{i t}^{T} \boldsymbol{\beta}+\alpha_{i}+\varepsilon_{i t}, \\
i=1, \ldots, N, \quad t=1, \ldots, T
\end{gathered}
$$

where:

$$
\varepsilon_{i t}-\sim \mathrm{N}\left(0, \sigma_{\varepsilon}^{2}\right) \text { for each } i, t
$$

$\alpha_{i}$ - group effects; if $\alpha_{i}$ are random, then $\alpha_{i} \sim \mathrm{N}\left(0, \sigma_{\varepsilon}^{2}\right) ;$

$\mathbf{x}_{i t}=\left[x_{k i t}\right]_{K \times 1}$ - vector of explanatory variables with $K$ coordinates;

$\boldsymbol{\beta}$ - vector of parameters (Kx1) identical for all $i$ and $t$;

$\gamma$ - autoregressive coefficient (Maddala, 2006; Dańska-Borsiak, 2011).

The most important estimators proposed for dynamic panel data models presented in the current literature are based on the generalised method of moments (GMM) and in-

2 Due to a partial lack of data we removed Serbia and Montenegro from the final analysis. 
strumental variable method resulting from it (Baltagi, 2005). This method makes it possible to take account of the heteroscedasticity and autocorrelation of random component, but also to distinguish and use appropriate instrumental variables. GMM is particularly useful to estimate models that contain endogenous or predetermined explanatory variables, and in which the process generating time series is not fully specified (Bond, 2002; Dańska-Borsiak, 2011). We assume that one may use instrumental variables $\boldsymbol{Z}$, which are independent of the random components of the model.

The estimator of the generalised method of moments takes the form of the following equation:

$$
\widehat{\boldsymbol{\beta}}=\left(\boldsymbol{X}^{T} \boldsymbol{Z} \boldsymbol{W}_{\boldsymbol{N}} \boldsymbol{Z}^{T} \boldsymbol{X}\right)^{-1}\left(\boldsymbol{X}^{T} \boldsymbol{Z} \boldsymbol{W}_{\boldsymbol{N}} \boldsymbol{Z}^{T} \boldsymbol{y}\right)
$$

in which $\boldsymbol{Z}=\left(Z_{1}, Z_{2}, \ldots, Z_{N}\right)$ is a properly structured matrix of instruments, while $\boldsymbol{W}_{\boldsymbol{N}}$ is a matrix of weights.

A model of this class requires specific estimation methods, other than methods used in static models. The most important proposed methods discussed in the literature are based on the generalised method of moments. Within a series of methods proposed to estimate dynamic panel data models the following two play the most prominent role in practice: GMM for the first differences model (FDGMM) and the system estimator GMM (GMM-SYS) as its extension. Each estimator can be discussed as a one- or two-step version. The matrix of instruments $\boldsymbol{Z}$ and the matrix of weights $\boldsymbol{W}_{\boldsymbol{N}}$ are decisive for the form of the estimator.

When we analyse the correctness of the estimated GMM model, we pay special attention to two tests: the Arellano-Bond autocorrelation test and the Sargan test of over-identifying restrictions.

In the former, differences model (FDGMM), the autocorrelation of the random component $\varepsilon_{i t}$ is an expected phenomenon. ${ }^{3}$ Higher-order autocorrelation would mean that instruments used to estimate the GMM are incorrect. Thus, the test which detects 2nd-order autocorrelation in the model can validate the correctness of moment conditions. Arellano and Bond proposed a 2nd-order autocorrelation test, in which null hypothesis assumes there is no such autocorrelation. Empirical statistics of Arellano-Bond test takes the following form:

$$
A R(2)=\frac{\Delta \widehat{\boldsymbol{\varepsilon}}_{-2}^{T} \Delta \widehat{\boldsymbol{\varepsilon}}_{*}}{\Delta \hat{\boldsymbol{\varepsilon}}^{1 / 2}}
$$

where $\Delta \widehat{\boldsymbol{\varepsilon}}_{-2}$ are second differences of vector $\Delta \boldsymbol{\varepsilon}$, while components of vector $\Delta \hat{\boldsymbol{\varepsilon}}_{*}$ are equal to components of $\Delta \varepsilon$ and two fist values are omitted (to enable the multiplication). $A R(2)$ statistics has got a normal distribution $N(0,1)$.

Another important test is the Sargan test applied to examine the correctness of overidentifying restrictions, not used in estimation. In accordance with the null hypothesis, instruments are appropriate and not correlated with random components of the first- differences model. Test construction is based on what was proposed by Sargan (1958) and Hansen (1982). Empirical statistics looks as follows:

$$
s=\Delta \widehat{\boldsymbol{\varepsilon}}^{T} \boldsymbol{Z}\left[\sum_{i=1}^{N} \boldsymbol{Z}_{i}^{T} \Delta \widehat{\boldsymbol{\varepsilon}} \Delta \widehat{\boldsymbol{\varepsilon}}^{T} \boldsymbol{Z}_{i}\right]^{-1} \boldsymbol{Z}^{T} \Delta \widehat{\boldsymbol{\varepsilon}}
$$

\footnotetext{
${ }^{3}$ If $\varepsilon_{i t}$ are independent, their first differences exhibit first-order correlation (see Dańska-Borsiak, 2011 for more details).
} 
Statistics $s$ with $\chi^{2}$ distribution and $q$ degrees of freedom, where $q$ means the number of columns in matrix $\boldsymbol{Z}$ decreased by the number of estimated parameters.

Finally, the model takes the following form:

$$
\begin{gathered}
F D I_{i t}=\beta_{0}+\gamma F D I_{i, t-1}+\beta_{1} G D P_{i t}+\beta_{2} G C F_{i t}+\beta_{3} I_{i t}+\beta_{4} N R R_{i t}+ \\
+\beta_{5} M T_{i t}+\beta_{6} E_{i t}+\beta_{7} M U E_{i t}+\beta_{8} E U R_{i t}+\beta_{9} D 1_{i t}+\beta_{10} D 2_{i t}+ \\
+\beta_{11} D 3_{i t}+\beta_{12} D 4_{i t}+\varepsilon_{i t}
\end{gathered}
$$

As an explained variable $\left(\mathrm{FDI}_{i t}\right)$ we took the value of FDI inward stock as \% of GDP for country $i$ in period $t$. Based on the overview of empirical studies conducted for panel studies, a number of variables have been selected that determine FDI inflow (BénassyQuéré et. al, 2005; Tun, Azman-Saini, \& Law, 2012). However, despite the plenitude of analyses devoted to individual variables what remains certain is that FDI inflow is the function of demand (market size) estimated by an entrepreneur and the assessment of investment risk (stability of business environment), i.e. it is guided by general investment deci-

\begin{tabular}{|c|c|c|c|}
\hline No. & Symbol & Definition & Source \\
\hline 1. & $G P_{\text {it }}$ & $\begin{array}{l}\text { GDP per capita growth (\% of GDP) for country } \\
i \text { in period } t \text {; }\end{array}$ & $\begin{array}{l}\text { World Bank national accounts data and } \\
\text { OECD National Accounts data files. }\end{array}$ \\
\hline 2. & $\mathrm{GCF}_{\text {it }}$ & $\begin{array}{l}\text { gross capital formation (\% of GDP) for country } \\
i \text { in period } t \text {; }\end{array}$ & $\begin{array}{l}\text { World Bank national accounts data and } \\
\text { OECD National Accounts data files. }\end{array}$ \\
\hline 3. & $l_{\text {it }}$ & $\begin{array}{l}\text { inflation, consumer process (annual \%) for } \\
\text { country } i \text { in period } t \text {; }\end{array}$ & $\begin{array}{l}\text { International Monetary Fund, International } \\
\text { Financial Statistics, and data files. }\end{array}$ \\
\hline 4. & $N R R_{\text {it }}$ & $\begin{array}{l}\text { total natural resources rents (\% of GDP) for } \\
\text { country } i \text { in period } t\end{array}$ & $\begin{array}{l}\text { Estimates based on sources and methods } \\
\text { described in The Changing Wealth of } \mathrm{Na} \text { - } \\
\text { tions: Measuring Sustainable Development } \\
\text { in the New Millennium (World Bank, 2011). }\end{array}$ \\
\hline 5. & $\mathrm{MT}_{\text {it }}$ & $\begin{array}{l}\text { merchandise trade (\% of GDP) for country } i \text { in } \\
\text { period } t \text {; }\end{array}$ & $\begin{array}{l}\text { World Trade Organization and World Bank } \\
\text { GDP estimates. }\end{array}$ \\
\hline 6. & $E_{i t}$ & $\begin{array}{l}\text { employment to population ratio } 15+\text { for coun- } \\
\text { try } i \text { in period } t \text {; }\end{array}$ & $\begin{array}{l}\text { International Labour Organization and the } \\
\text { ILOSTAT database. }\end{array}$ \\
\hline 7. & $\mathrm{MUE}_{\text {it }}$ & EU membership for country $i$ in period $t$; & EU Commission. \\
\hline 8. & EUR $R_{\text {it }}$ & Eurozone membership for country $i$ in period $t$ & EU Commission. \\
\hline
\end{tabular}
sion-making rules formulated by Keynes (Lautier \& Moreau, 2012).

Table 2. Explanatory variables: Definitions and sources of data

Source: own study.

The model also included variables reflecting the affiliation with one of the five groups of countries -distinguished earlier based on the dendrogram - that exhibit similar institutional quality. Since there was only Estonia in group $\mathrm{V}$, a country whose institutional quality is viewed as the highest among CEECs covered by the study, it became the reference point for comparison of other, earlier distinguished groups:

$\mathrm{D} 1_{\mathrm{it}}$ - group 1 consisting of countries representing a similar level of institutional quality, distinguished based on the dendrogram (Hungary, Romania, Slovakia, Croatia) for country $i$ in period $t$;

D $2_{\text {it }}$ - group 2 including countries representing a similar level of institutional quality, distinguished based on the dendrogram (Latvia, Lithuania, Poland, Slovenia, the Czech Republic) for country $i$ in period $t$;

D $3_{\text {it }}$ - group 3 consisting of countries representing a similar level of institutional quality, distinguished based on the dendrogram (Albania, Montenegro) for country $i$ in period $t$; 
D $4_{\text {it }}$ - group 4 including countries representing a similar level of institutional quality, distinguished based on the dendrogram (Bosnia and Herzegovina, Serbia, Moldova, Ukraine, Bulgaria) for country $i$ in period $t$.

\section{RESULTS AND DISCUSSION}

Due to higher statistical value measured with the Arellano test, we presented estimates obtained using the GMM-SYS method (Table 3). The table contains absolute values of t-statistic, while the last but one line shows $A R(2)$, empirical values of the Arellano-Bond statistic that validates the second-order autocorrelation of the random component in the first differences model, in which the null hypothesis reads: there is no second-order autocorrelation.

Table 3. Results of the estimation of parameters in dynamic panel data models

\begin{tabular}{|c|c|c|c|}
\hline $\begin{array}{c}\text { Explanatory variables and } \\
\text { selected characteristics }\end{array}$ & $\begin{array}{c}\text { Parameter } \\
\text { estimation }\end{array}$ & $\boldsymbol{z}$ & $\boldsymbol{p}$ \\
\hline Constant & 30.951 & 7.045 & 0.0001 \\
\hline$F D I_{i, t-1}$ & 0.440 & 6.203 & 0.0001 \\
\hline $\mathrm{D} 1_{\text {it }}$ & -12.246 & -4.918 & 0.0001 \\
\hline $\mathrm{D} 2_{\text {it }}$ & -21.299 & -6.361 & 0.0001 \\
\hline $\mathrm{D} 3_{\text {it }}$ & -12.180 & -3.464 & 0.0004 \\
\hline $\mathrm{D} 4_{\text {it }}$ & $-4,355$ & $-1,780$ & 0.0751 \\
\hline $\mathrm{MU} \mathrm{E}_{\text {it }}$ & 13.337 & 5.610 & 0.0001 \\
\hline $\mathrm{N}$ & -1.87638 & $\mathrm{x}$ & {$[0.061]$} \\
\hline Test AR(2) $[p$-value $]$ & 150 & $\mathrm{x}$ & $\mathrm{x}$ \\
\hline
\end{tabular}

$p$ - probability value $(p \in[0,1])$.

Source: own study.

Results of the Arellano-Bond autocorrelation test suggest there are no grounds for the rejection of the null hypothesis, which means there is no second-order autocorrelation. The assessment of autoregression coefficient is statistically significant and positive. FDI inward stock as \% of GDP of the previous year implies increases in FDI inward stock as \% of GDP. The obtained results come as a surprise. They do not confirm the impact of most explanatory variables on FDI inward stock as \% of GDP. However, the model confirmed that the EU membership is positively and statistically significantly correlated with FDI inward stock as \% of GDP. Institutional quality turned out to be a statistically significant variable in countries covered by the study. Coefficients estimated for variables indicating affiliation to a specific group of countries demonstrate that FDI inward stock as \% of GDP in all distinguished groups is lower than in Estonia.

The results obtained in our study are in accordance with the literature addressing empirical FDI incentives, which stresses the importance of institutions for FDI inflow (Dorożyński et al., 2019; Buchanan et al., 2012; Daude \& Stein, 2007; Bénassy-Quéré et al., 2005). This article reveals that institutional quality tends to be an important stimulus in attracting FDI inflows in the CEE countries.

The results obtained from this study are useful for policymakers. Our findings allow us to formulate policy implications that stress the role of institutional quality, as an important determinant in attracting FDI inflows. The CEECs are highly dependent on FDI inflows and 
foreign capital. Without FDI inflows, economic development can be hindered. In other words, the authorities at different levels (local, regional, national) should improve the quality of institutions to attract and retain companies with foreign capital. Otherwise, foreign investors might be less interested in investing in Central Eastern Europe.

\section{CONCLUSIONS}

The main goal of the article was to assess the impact of institutional quality on the inflow of foreign direct investment in countries of Central and Eastern Europe. The conducted analyses have led us to the following conclusions:

1. Most researchers agree that institutional quality is one of the main determinants of FDI inflow.

2. Central and Eastern Europe is currently one of the most attractive areas to invest. Taking account of the amount of inflowing capital, the EU Member States, in particular Visegrad Group countries, are leaders in the region.

3. Measuring institutional quality remains problematic to many researchers as there is no coherent measure. This is why we tried to develop our own measure built from 23 partial variables from the $\mathrm{GCl}$. In the group of countries covered by the study, Estonia is an undisputed leader when it comes to the quality of institutions.

4. Simultaneously, it turned out that the examined countries can be divided into groups representing similar institutional quality. Using the hierarchic cluster analysis, we selected five such groups. Countries that belong to these five groups exhibit some identical features, e.g. geographic proximity, the level of economic development, or EU membership.

5. Using dynamic panel data models, we examined the impact of institutional quality upon FDI inflow. It turned out that membership in a particular group of countries similar to one another in institutional quality strongly impacts their investment attractiveness.

Although this study provides important theoretical contributions and useful implications for policy makers in the examined countries, we realise that it has limitations. Firstly, the study exclusively covers countries from Central and Eastern Europe, i.e. a group of countries sharing specific historical experiences and bound with geographic proximity. Hence, it is hard to compare the obtained results with surveys conducted in other countries or regions, including emerging economies such as China or India, which rather abundantly feature in the literature on economics and international management. This is also why possibilities to generalize the obtained results are rather limited. Secondly, we used statistical data until only 2017, as the GCl 2017/2018 edition significantly changed the methodology used to estimate the indicator and data published for periods after 2017 became non-comparable to earlier data. The same can be said about data pre-dating 2007. Thus, the possibility to conduct analogous panel studies based on this database but covering a longer time horizon is not feasible in practice. Thirdly, using the $\mathrm{GCl}$ coefficient means we deal with a closed set of comparable explanatory (independent) variables. 


\section{REFERENCES}

Alesina, A., \& Perotti, R. (1996). Income distribution, political instability and investment. European Economic Review, 40(6), 1203-1228.

Al-Sadig, A. (2009). The Effects of Corruption on FDI Inflows. Cato Journal, 29(2), 267-294.

Ali, F., Fiess, N., \& MacDonald, R. (2010). Do institutions matter for foreign direct investment?. Open Economies Review, 21(2), 201-219.

Arel-Bundock, V. (2017). The Political Determinants of Foreign Direct Investment: A Firm-Level Analysis. International Interactions, 43(3), 424-452.

Bailey, N. (2018). Exploring the relationship between institutional factors and FDI attractiveness: A meta-analytic review. International Business Review, 27(1), 139-148.

Baltagi, B.H. (2005). Econometric analysis of panel data. Third Edition. Chichester, England: John Wileys \& Sons.

Bénassy-Quéré, A., Coupet, M., \& Mayer, T. (2005). Institutional Determinants of Foreign Direct Investment (CEPII Working Paper, 2005-05). Retrieved from http://citeseerx.ist.psu.edu/viewdoc/download?doi=10.1.1.182.6961\&rep=rep1\&type=pdf on September 3, 2019.

Bénassy-Quéré, A., Fontagné, L., \& Lahrèche-Révil, A. (2003). Tax Competition and Foreign Direct Investment (CEPII Working Paper, 17). Retrieved from http://citeseerx.ist.psu.edu/viewdoc/download?doi=10.1.1.182.6961\&rep=rep1\&type=pdf on September 3, 2019.

Bond, S.R. (2002). Dynamic panel data models: a guide to micro data methods and practice. Portuguese Economic Journal, 1, 141-162. https://doi.org/10.1007/s10258-002-0009-9

Brada, J.C., Kutan, A.M., \& Yigit, T.M. (2006). The Effects of Transition and Political Instability on Foreign Direct Investment Inflows. Economics of Transition, 14(4), 649-680.

Bruno, R.L. (2008). Rule of Law, Institutional Quality and Information. IZA Discussion Paper, 3497, 1-32.

Buchanan, B.G., Le, Q.V., \& Rishi, M. (2012). Foreign direct investment and institutional quality: Some empirical evidence. International Review of Financial Analysis, 21, 81-89.

Daniele, V., \& Marani, U. (2006). Do institutions matter for FDI: A comparative analysis of the MENA countries. MPRA Paper, 2426, 1-28.

Dańska-Borsiak, B. (2011). Dynamiczne modele panelowe $w$ badaniach ekonomicznych. Łódź: Wydawnictwo Uniwersytetu Łódzkiego.

Daude, C., \& Stein, E. (2007). The quality of institutions and foreign direct investment. Economics \& Politics, 19(3), 317-344.

Dorożyński, T., Dobrowolska, B., \& Kuna-Marszałek, A. (2019). Institutional Quality as a determinant of FDI inflow: the case of Central and Eastern European countries. Journal of Management and Financial Studies, 39 (March), 103-122.

Eicher, T., Helfman, L., \& Lenkoski, A. (2011). Robust FDI Determinants: Bayesian Model Averaging in the Presence of Selection Bias. Washington: University of Washington.

Essien, J., Barikui, T., Abuba, S., \& Igbara, F. (2015). The Impact of National Security on Foreign Direct Investment (FDI) in Nigeria. IOSR Journal of Business and Management, 17(5), 69-74.

Fatica, S. (2009). Taxation and the quality of institutions: asymmetric effects on FDI. MPRA Paper, 24179, $1-61$.

Feld, L.P., \& Heckemeyer, J.H. (2008). FDI and Taxation. A Meta-Study. ZEW Discussion Paper, 08-128, 1-57. 
Guerin, S., \& Manzocchi, S. (2009). Political regime and FDI from advanced to emerging countries. Review of World Economics, 145(1), 75-91.

Francis, J., Zheng, C., \& Mukherji, A. (2009). An institutional perspective on foreign direct investment: A multi-level framework. Management International Review, 49(5), 565-583.

Habib, M., \& Zurawicki, L. (2010). Corruption and Foreign Direct Investment: What Have We Learned. International Business and Economics Research Journal, 9(7), 1-9.

Hausmann, R., \& Fernández-Arias, E. (2000). Foreign Direct Investment: Good Cholesterol?. Inter American Development Bank Working Papers, 417, 1-46.

Hayat, A. (2019). Foreign Direct Investment, Institutional Quality, and Economic Growth. The Journal of International Trade and Economic Development, 1, 1-20.

Jabri, A., \& Brahim, M. (2015). Institutional Determinants Of Foreign Direct Investment In MENA Region: Panel Co-Integration Analysis. Journal of Applied Business Research, 31(5), 2001-2012.

James, G., Witten, D., Hastie, T., \& Tibshirani, R. (2014). An Introduction To Statistical Learning with Applications in R. New York: Springer.

Jensen, N. (2008). Political Risk, Democratic Institutions, and Foreign Direct Investment. The Journal of Politics, 70(04), 1040-1052.

Jude, C., \& Levieuge, G. (2015). Growth effect of FDI in developing economies: The role of institutional quality. Direction Générale Des Études et des Relations Internationales, Banque de France, 1-33.

Khan, M.A., \& Samad, G. (2010). Intellectual Property Rights and Foreign Direct Investment: Analysis of 14 South and South East Asian Countries, 1970-2005. Applied Econometrics and International Development, 10(1), 219-230.

Kurul, Z., \& Yalta, A.Y. (2017). Relationship between Institutional Factors and FDI Flows in Developing Countries: New Evidence from Dynamic Panel Estimation. Economies, 5(2), 1-10.

Lasek, M. (2002). Data mining. Zastosowania w analizach i ocenach klientów bankowych. Warszawa: Biblioteka Menedżera i Bankowca.

Lautier, M., \& Moreau, F. (2012), Domestic Investment and FDI in Developing Countries: The Missing Link. Journal of Economic Development, 37(3), 1-23.

Lee, M., \& Park, D. (2013). Intellectual Property Rights, Quality of Institutions, and Foreign Direct Investment into Developing Asia (ADB Economics Working Paper Series, 354). Retrieved from https://www.adb.org/publications/intellectual-property-rights-quality-institutions-foreign-direct-investment-developing-asia 3 on September 3, 2019.

Lemma, T.T., \& Negash, M. (2013). Institutional, macroeconomic and firm-specific determinants of capital structure: The African evidence. Management Research Review, 36(11), 1081-1122.

Levchenko, A. (2004). Institutional Quality and International Trade (HIMF Working Paper, 04/231). Retrieved from https://www.imf.org/en/Publications/WP/Issues/2016/12/31/InstitutionalQuality-and-International-Trade-17842 on September 3, 2019.

Madani, S., \& Nobakht, M. (2014). Political Regimes and FDI Inflows: Empirical Evidence from Upper Middle Income Countries. Journal of Finance and Economics, 2(3), 75-82.

Maddala, G.S. (2006). Ekonometria. Warszawa: PWN.

Masron, T.A., \& Naseem, N.A. (2017). Institutional Quality and Foreign Direct Investment in ASEAN. Institutions and Economies, 9(4), 5-30.

Mengistu, A.A., \& Adhikary, B. (2011). Does good governance matter for FDI inflows? Evidence from Asian economies. Asia Pacific Business Review, 17(3), 281-299.

Miningou, E.W., \& Tapsoba, S.J. (2017). Education Systems and Foreign Direct Investment: Does External Efficiency Matter? (IMF Working Paper, 17/79). Retrieved from https://www.imf.org/en/ 
Publications/WP/Issues/2017/03/30/Education-Systems-and-Foreign-Direct-Investment-DoesExternal-Efficiency-Matter-44778 on September 3, 2019.

Moore, M. (1998). Death without Taxes: Democracy, State Capacity, and Aid Dependency in the Fourth World. In G. White \& M. Robinson (Eds.), Towards a Democratic Developmental State (pp. 84-123). New York: Oxford University Press.

Nielsen, B.B., Asmussen, Ch.G., \& Weatherall, C.D. (2017). The location choice of foreign direct investments: Empirical evidence and methodological challenges. Journal of World Business, 52, 62-82.

Petersen, N. (2013). Antitrust Law and the Promotion of Democracy and Economic Growth. Journal of Competition Law \& Economics, 9, 593-636.

Rigobon, R., \& Rodrik, D. (2004). Rule of Law, Democracy, Openness, and Income: Estimating the Interrelationships (NBER Working Paper, 10750). Retrieved from https://www.nber.org/papers/w10750 on September 3, 2019.

Rodrik, D., Subramanian, A., \& Trebbi, F. (2004). Institutions Rule: The Primacy of Institutions over Geography and Integration in Economic Development. Journal of Economic Growth, 9, 131-165.

Sabir, S., Rafique, A., \& Abbas, K. (2019). Institutions and FDI: evidence from developed and developing countries. Financial Innovations, 5(8), 1-20. https://doi.org/10.1186/s40854-019-0123-7

Stoian, R.C., \& Vickerman, R. (2005). The Interplay between Foreign Direct Investment, Security and European Integration: The Case of the Central and Eastern European Countries. Proceedings in Academy of International Business Annual Meeting, Quebec, Canada. Retrieved from http://kar.kent.ac.uk/9873/ on July 15, 2019.

Tanaka, H., \& Iwaisako, T. (2014). Intellectual property rights and foreign direct investment: A welfare analysis. European Economic Review, 67, 107-124.

Tun, Y.L., Azman-Saini, W.N.W., \& Law, S.H. (2012). International Evidence on the link between Foreign Direct Investment and Institutional Quality. Engineering Economics, 23(4), 379-386.

Walsh, J.W., \& Yu, J. (2010). Determinants of Foreign Direct Investment: A Sectoral and Institutional Approach (IMF Working Paper, 10/187). Retrieved from https://www.imf.org/exter$\mathrm{nal} / \mathrm{pubs} / \mathrm{ft} / \mathrm{wp} / 2010 / \mathrm{wp} 10187$. df on September 3, 2019.

Zheng, Y. (2011). Credibility and Flexibility: Political Institutions, Governance, and Foreign Direct Investment. International Interactions, 37(3), 293-319. 


\section{Appendix}

Table A1. Partial ranking of institutional quality for 17 CEECs

\begin{tabular}{|c|c|c|c|c|c|c|c|c|c|c|c|c|c|c|c|c|c|c|}
\hline \multirow{2}{*}{ Symbol } & \multirow{2}{*}{ Variables } & \multicolumn{17}{|c|}{ Countries } \\
\hline & & $\mathrm{AL}$ & BA & BG & HR & CZ & EE & HU & LV & & & ME & PL & Ro & $\mathrm{xS}$ & SK & SI & UA \\
\hline \multicolumn{19}{|c|}{ Pillar 1: Institutions/index: Public institutions } \\
\hline $\mathrm{X}_{1}$ & Property rights & 15 & 16 & 12 & 11 & 5 & 1 & 9 & 2 & 4 & 14 & 6 & 8 & 10 & 13 & 7 & 3 & 17 \\
\hline $\mathrm{X}_{2}$ & Intellectual prop & 15 & 17 & 13 & 9 & 3 & 1 & 4 & 5 & 7 & 12 & 11 & 8 & 10 & 14 & 6 & 2 & 16 \\
\hline$X_{3}$ & Diversion of pu & 9 & 7 & 14 & 8 & 13 & 1 & 12 & 5 & 6 & 17 & 2 & 3 & 11 & 10 & 15 & 4 & 16 \\
\hline$X_{4}$ & Public trust in politic & 5 & 13 & 9 & 10 & 15 & 1 & 14 & 6 & 4 & 11 & 2 & 7 & 17 & 12 & 16 & 3 & 8 \\
\hline$x_{5}$ & Irregular payments a & 12 & 14 & 10 & 9 & 8 & 1 & 6 & 5 & 4 & 16 & 7 & 3 & 11 & 13 & 15 & 2 & 17 \\
\hline$X_{6}$ & Judic & 15 & 11 & 13 & 10 & 2 & 1 & 6 & , & 7 & 17 & 8 & 3 & 9 & 14 & 12 & 4 & 16 \\
\hline$x_{7}$ & $\begin{array}{l}\text { Favou } \\
\text { ernm }\end{array}$ & 5 & 9 & 11 & 8 & 10 & 1 & 14 & 7 & 4 & 16 & 2 & 3 & 15 & 13 & 17 & 6 & 12 \\
\hline$X_{8}$ & nding & \begin{tabular}{|l|}
4 \\
\end{tabular} & 16 & 8 & 11 & 3 & 1 & 12 & 5 & 7 & 9 & 2 & 6 & 13 & 15 & 14 & 10 & 17 \\
\hline$X_{9}$ & Burd & 2 & 11 & 5 & 16 & 13 & 1 & 15 & 4 & 6 & 8 & 3 & 12 & 8 & 17 & 14 & 7 & 10 \\
\hline $\mathrm{X}_{10}$ & $\begin{array}{l}\text { Effici } \\
\text { in set }\end{array}$ & 5 & 12 & 11 & 16 & 6 & 1 & 7 & 9 & 3 & 14 & 2 & 4 & 10 & 13 & 17 & 8 & 15 \\
\hline $\mathrm{X}_{11}$ & $\begin{array}{l}\text { Effici } \\
\text { in ch }\end{array}$ & 4 & 11 & 9 & 14 & 5 & 1 & 12 & 7 & 3 & 15 & 2 & 8 & 10 & 13 & 17 & 6 & 16 \\
\hline $\mathrm{X}_{12}$ & $\begin{array}{l}\text { Tran } \\
\text { icym }\end{array}$ & 7 & 17 & 15 & 11 & 9 & 1 & 14 & 4 & 3 & 5 & 8 & 13 & 16 & 10 & 6 & 2 & 12 \\
\hline$x_{1}$ & Busin & 14 & \begin{tabular}{|l|}
9 \\
\end{tabular} & 17 & 3 & 4 & 2 & 6 & & 7 & 11 & 10 & 12 & 13 & 15 & 5 & 1 & 16 \\
\hline $\mathrm{X}_{14}$ & $\begin{array}{l}\text { Busine } \\
\text { lence }\end{array}$ & 14 & 13 & 17 & 5 & 4 & 2 & 6 & 3 & 7 & 11 & 8 & 10 & 12 & 15 & 9 & 1 & 16 \\
\hline \begin{tabular}{l|l}
$X_{15}$ \\
\end{tabular} & Orga & 14 & 13 & 17 & 7 & 4 & 1 & 8 & 2 & 5 & 12 & 9 & 6 & 10 & 15 & 11 & 3 & 16 \\
\hline $\mathrm{X}_{16}$ & / of police services & \begin{tabular}{|l|}
9 \\
\end{tabular} & 8 & 15 & 3 & 12 & 1 & 4 & 5 & 7 & 16 & 6 & 10 & 11 & 13 & 14 & 2 & 17 \\
\hline \multicolumn{19}{|c|}{ Pillar 2: Higher education and training/index: Quality of education } \\
\hline T & the education system & 4 & 9 & 12 & 11 & 2 & 1 & 14 & 8 & 6 & 16 & 5 & 10 & 15 & 13 & 17 & 3 & 7 \\
\hline \multicolumn{19}{|c|}{ Pillar 3: Goods market efficiency/index: Domestic competition } \\
\hline $\mathrm{X}_{18}$ & $\begin{array}{l}\text { Effec } \\
\text { polic }\end{array}$ & 13 & 14 & 12 & 11 & 3 & 1 & 7 & 6 & 8 & 16 & 10 & 4 & 9 & 17 & 5 & 2 & 15 \\
\hline $\mathrm{X}_{19}$ & $\begin{array}{l}\text { Effect of taxation on incentives to } \\
\text { invest }\end{array}$ & 10 & 12 & 3 & 17 & 5 & 1 & 9 & 4 & 6 & 8 & 2 & 7 & 15 & 13 & 11 & 14 & 16 \\
\hline \begin{tabular}{l|l}
$X_{20}$ & $f$
\end{tabular} & Releva & 12 & 14 & 16 & 7 & 2 & 1 & 6 & 4 & 9 & 13 & 8 & 10 & 11 & 15 & 3 & 5 & 17 \\
\hline$X_{21}$ & Business impact of rules on FDI & 7 & 14 & 13 & 16 & 3 & 1 & 4 & 6 & 10 & 11 & 5 & 9 & 8 & 12 & 2 & 15 & 17 \\
\hline \multicolumn{19}{|c|}{ Pillar 4: Labour market efficiency/index: Flexibility } \\
\hline$x_{22}$ & on on incentives to & 4 & 12 & 3 & 16 & 6 & 1 & 7 & 5 & 10 & 9 & 2 & 8 & 14 & 11 & 15 & 17 & 13 \\
\hline \multicolumn{19}{|c|}{ Pillar 5: R\&D Innovation } \\
\hline$x_{23}$ & $\begin{array}{l}\text { Government procurement of ad- } \\
\text { vanced technology products }\end{array}$ & 3 & 16 & 5 & 15 & 4 & 1 & 12 & 9 & 7 & 17 & 2 & 6 & 11 & 13 & 14 & 10 & 8 \\
\hline
\end{tabular}

AL - Albania, BA - Bosnia and Herzegovina, BG - Bulgaria, HR - Croatia, CZ - Czech Republic, EE - Estonia, HU Hungary, LV - Latvia, LT - Lithuania, MD - Moldova, ME - Montenegro, PL - Poland, RO - Romania, XS - Serbia, SK - Slovakia, SI - Slovenia, UA - Ukraine.

Source: own elaboration based on $\mathrm{GCl}$. 
Table A2. Institutional quality ranking for five groups of countries

\begin{tabular}{|c|c|c|c|c|c|c|}
\hline \multirow{2}{*}{ Symbol } & \multirow{2}{*}{ Variables } & \multicolumn{5}{|c|}{ Countries } \\
\hline & & Group I & Group II & Group III & Group IV & Group V \\
\hline \multicolumn{7}{|c|}{ Pillar 1: Institutions/index: Public institutions } \\
\hline $\mathrm{X}_{1}$ & Property rights & 3 & 2 & 4 & 5 & 1 \\
\hline$X_{2}$ & Intellectual property protection & 3 & 2 & 4 & 5 & 1 \\
\hline$X_{3}$ & Diversion of public funds & 4 & 3 & 2 & 5 & 1 \\
\hline $\mathrm{X}_{4}$ & Public trust in politicians & 5 & 3 & 2 & 4 & 1 \\
\hline$X_{5}$ & Irregular payments and bribes & 4 & 2 & 3 & 5 & 1 \\
\hline$X_{6}$ & Judicial independence & 3 & 2 & 4 & 5 & 1 \\
\hline $\mathrm{X}_{7}$ & Favouritism in decisions of government officials & 5 & 3 & 2 & 4 & 1 \\
\hline $\mathrm{X}_{8}$ & Efficiency of government spending & 4 & 3 & 2 & 5 & 1 \\
\hline$X_{9}$ & Burden of government regulation & 5 & 3 & 2 & 4 & 1 \\
\hline$X_{10}$ & $\begin{array}{l}\text { Efficiency of the legal framework in settling } \\
\text { disputes }\end{array}$ & 4 & 3 & 2 & 5 & 1 \\
\hline $\mathrm{X}_{11}$ & $\begin{array}{l}\text { Efficiency of the legal framework in challenging } \\
\text { regulations }\end{array}$ & 5 & 3 & 2 & 4 & 1 \\
\hline $\mathrm{X}_{12}$ & Transparency of government policymaking & 5 & 4 & 3 & 2 & 1 \\
\hline $\mathrm{X}_{13}$ & Business costs of terrorism & 3 & 2 & 4 & 5 & 1 \\
\hline $\mathrm{X}_{14}$ & Business costs of crime and violence & 3 & 2 & 4 & 5 & 1 \\
\hline $\mathrm{X}_{15}$ & Organised crime & 3 & 2 & 4 & 5 & 1 \\
\hline $\mathrm{X}_{16}$ & Reliability of police services & 4 & 2 & 3 & 5 & 1 \\
\hline \multicolumn{7}{|c|}{ Pillar 2: Higher education and training/index: Quality of education } \\
\hline $\mathrm{X}_{17}$ & Quality of the educational system & 5 & 3 & 2 & 4 & 1 \\
\hline \multicolumn{7}{|c|}{ Pillar 3: Goods market efficiency/index: Domestic competition } \\
\hline $\mathrm{X}_{18}$ & Effectiveness of antimonopoly policy & 3 & 2 & 4 & 5 & 1 \\
\hline $\mathrm{X}_{19}$ & Effect of taxation on incentives to invest & 5 & 3 & 2 & 4 & 1 \\
\hline$X_{20}$ & Relevance of trade barriers & 2 & 3 & 4 & 5 & 1 \\
\hline$X_{21}$ & Business impact of rules on FDI & 3 & 4 & 2 & 5 & 1 \\
\hline \multicolumn{7}{|c|}{ Pillar 4: Labour market efficiency/index: Flexibility } \\
\hline$X_{22}$ & Effect of taxation on incentives to work & 5 & 4 & 2 & 3 & 1 \\
\hline \multicolumn{7}{|c|}{ Pillar 5: R\&D Innovation } \\
\hline$x_{23}$ & $\begin{array}{l}\text { Government procurement of advanced tech- } \\
\text { nology products }\end{array}$ & 4 & 3 & 2 & 5 & 1 \\
\hline
\end{tabular}

group I: Hungary, Romania, Slovakia, Croatia; group II: Latvia, Lithuania, Poland, Slovenia, Czech Republic; group III: Albania, Montenegro, group IV: Bosnia and Herzegovina, Serbia, Moldova, Ukraine, Bulgaria; group V: Estonia. Source: own elaboration based on $\mathrm{GCl}$. 


\section{Authors}

The contribution share of authors is equal and amounted to $1 / 3$ each of them.

\section{Tomasz Dorożyński}

Associate Professor at the Department of International Trade, Institute of Economics, Faculty of Economics and Sociology, University of Lodz (Poland). His research work focuses on the internationalization, FDI, investment incentives, EU cohesion policy, and regional development.

Correspondence to: dr hab. Tomasz Dorożyński, Department of International Trade, Faculty of Economics and Sociology, University of Lodz, 41/43 Rewolucji 1905 r. St., 90-214 Łódź, e-mail: tomasz.dorozynski@uni.lodz.pl

ORCID (1) http://orcid.org/0000-0003-3625-0354

\section{Bogusława Dobrowolska}

$\mathrm{PhD}$ in economic sciences, Adjunct at the Department of Economic and Social Statistics at the Faculty of Economics and Sociology, University of Lodz. Her scientific interests include the application of statistical methods in economic and social research. She is the author of several dozen of scientific articles. Since 2013, she gives classes accredited by Predictive Solutions (previously IBM SPSS Poland). The classes concern statistics with the application of PS IMAGO software.

Correspondence to: dr Bogusława Dobrowolska, Department of Economic and Social Statistics, Faculty of Economics and Sociology, University of Lodz, 41/43 Rewolucji 1905 r. St., 90-214 Łódź, e-mail: boguslawa.dobrowolska@uni.lodz.pl

ORCID (ib) http://orcid.org/0000-0003-3497-6223

\section{Anetta Kuna-Marszałek}

Associate Professor and the head of Department of International Trade, Institute of Economics, Faculty of Economics and Sociology, University of Lodz (Poland). Her primary research interests focus on the various aspects of contemporary economics, including research on the world trading system, the interlinks between trade liberalisation and environmental policies, and green economy. She is currently working on the internationalisation of business activities, FDI, and support instruments for exporters.

Correspondence to: dr hab. Anetta Kuna-Marszałek, Department of International Trade, Faculty of Economics and Sociology, University of Lodz, 41/43 Rewolucji 1905 r. St., 90-214 Łódź, e-mail: anetta.marszalek@uni.lodz.pl

ORCID (1) http://orcid.org/0000-0001-5687-7272

\section{Acknowledgements and Financial Disclosure}

The authors would like to thank the anonymous referees for their useful comments, which allowed to increase the value of this article.

\section{Copyright and License}

This article is published under the terms of the Creative Commons Attribution - NoDerivs (CC BY-ND 4.0) License

http://creativecommons.org/licenses/by-nd/4.0/

Published by the Centre for Strategic and International Entrepreneurship - Krakow, Poland 